\title{
Evolution of the Corticotropin-releasing Hormone Signaling System and Its Role in Stress-induced Phenotypic Plasticity
}

\author{
ROBERT J. DENVER ${ }^{a}$
}

Department of Biology, The University of Michigan, Ann Arbor, Michigan 48109, USA

\begin{abstract}
Developing animals respond to variation in their habitats by altering their rates of development and/or their morphologies (i.e., they exhibit phenotypic plasticity). In vertebrates, one mechanism by which plasticity is expressed is through activation of the neuroendocrine system, which transduces environmental information into a physiological response. Recent findings of ours with amphibians and of others with mammals show that the primary vertebrate stress neuropeptide, corticotropin-releasing hormone (CRH), is essential for adaptive developmental responses to environmental stress. For instance, $\mathrm{CRH}$-dependent mechanisms cause accelerated metamorphosis in response to pond-drying in some amphibian species, and intrauterine fetal stress syndromes in humans precipitate preterm birth. CRH may be a phylogenetically ancient developmental signaling molecule that allows developing organisms to escape deleterious changes in their larval/fetal habitat. The response to CRH is mediated by at least two different receptor subtypes and may also be modulated by a secreted binding protein.
\end{abstract}

\section{INTRODUCTION}

Embryonic development tends to be buffered against unpredictable environmental effects. ${ }^{1}$ By contrast, postembryonic development is strongly influenced by the external environment (i.e., animals exhibit phenotypic plasticity). The term phenotypic plasticity refers to the modification of developmental pathways in response to environmental cues. ${ }^{2}$ If a variable phenotype confers a selective advantage over a fixed phenotype, then the plasticity is considered adaptive. Adaptive phenotypic plasticity may allow developing organisms to respond to deleterious (i.e., stressful) changes in their habitat ${ }^{3}$ and may be an important mechanism in speciation. ${ }^{4}$

Amphibian tadpoles show strong responses to environmental signals, both by expressing multiple, discontinuous phenotypes (i.e., polyphenism ${ }^{5}$ ) and by exhibiting continuous variation in the timing of developmental events (i.e., plasticity in the timing of metamorphosis ${ }^{3,5}$ ). While the timing of metamorphosis is determined by both genetic and environmental factors, alterations in the rates of growth and development ultimately depend upon the activity of several endocrine systems. Because of the dramatic phenotypic plasticity exhibited by amphibians and the importance of hormonal control, amphibians make excellent models for understanding the ecolog-

${ }^{a}$ Address for correspondence: Department of Biology, 3077 Natural Science Building, the University of Michigan, Ann Arbor, MI 48109-1048. 734/936-6625 (voice); 734/674-0884 (fax).

e-mail: rdenver@umich.edu 
ical factors that influence development, and the neuroendocrine mechanisms that mediate the response of the organism to a changing environment. This review focuses on the role that the neuroendocrine stress axis plays in mediating responses of developing animals, with particular emphasis on amphibians, to environmental stress.

\section{HORMONAL CONTROL OF AMPHIBIAN METAMORPHOSIS}

Gudernatsch ${ }^{6}$ provided the first evidence that a substance produced by the thyroid gland could influence tadpole metamorphosis. He discovered that feeding tadpoles horse thyroid extract caused precocious metamorphosis. Following Gudernatsch's discovery, many investigators have examined the role of the thyroid gland in amphibian tadpoles, and now the consensus view is that thyroid hormone (TH) is the primary morphogen controlling amphibian metamorphosis. ${ }^{7}$ While TH is essential for metamorphosis, the coordinated functioning of multiple interacting endocrine systems is required for normal development. ${ }^{8}$ For example, corticosteroids $(\mathrm{CORT})^{8}$ have been implicated in the positive control of metamorphosis through synergy with TH. It is noteworthy that these two hormones have similar mechanisms of action (receptors are ligand-activated transcription factors) and their production may be controlled by common neural pathways in tadpoles ${ }^{8,9}$ (see below). In addition to hormonal effectors of metamorphosis, the pituitary gland produces the protein hormone prolactin (PRL), which may serve to inhibit the actions of TH. ${ }^{9}$

An intact hypothalamus and pituitary portal circulation are essential for metamorphosis. ${ }^{9}$ The hypothalamus produces releasing and release-inhibiting hormones that are essential for regulating pituitary secretion of thyrotropin (TSH), which stimulates TH production by the thyroid glands, adrenocorticotropin (ACTH), which stimulates CORT secretion by the interrenal glands, and prolactin (PRL). In mammals the principal stimulatory hypothalamic regulator of TSH secretion is the tripeptide amide thyrotropin-releasing hormone (TRH). TRH stimulates TSH in adult ectotherms (frogs and turtles), ${ }^{10}$ but,the stimulatory action of TRH on TSH secretion develops after metamorphic climax in amphibians, ${ }^{11,12}$ and the bulk of evidence suggests that TRH does not influence TSH release in tadpoles. ${ }^{9}$ The role that this molecule plays during metamorphosis may be to control PRL release, although this possibility has yet to be tested directly. ${ }^{9}$

\section{CORTICOTROPIN-RELEASING HORMONE IS A THYROTROPIN-RELEASING FACTOR}

Corticotropin-releasing hormone $(\mathrm{CRH})$ is a 41-amino-acid straight-chain polypeptide that was first isolated for its ability to stimulate ACTH secretion in mammals ${ }^{13}$; CRH also stimulates ACTH secretion by frog pituitaries. ${ }^{14}$ The regulation of ACTH secretion by CRH is commonly considered to be the primary hypophysiotropic role for this neuropeptide. ${ }^{15}$ The vertebrate CRH family of peptides is composed of at least two functionally distinct paralogous lineages. $\mathrm{CRH}$ molecules have been isolated from the brains of representatives of most vertebrate classes and appear homologous. By contrast with $\mathrm{CRH}$, the phylogeny of the paralogous lineage 
(or lineages?) sauvagine-urotensin I-urocortin awaits clarification. Urotensin I, a 40amino-acid peptide, was first isolated from the caudal neurosecretory organ (urophysis) of the common sucker, Catostomus commersoni ${ }^{16}$; sauvagine, a 40 -amino-acid peptide, was isolated from the skin of the frog Phyllomedusa sauvagei ${ }^{17}$; and, most recently, urocortin, a 40-amino-acid peptide, was cloned from rodent and human brain. ${ }^{18}$ The major role for $\mathrm{CRH}$ appears to be as a hypophysiotropin, while the related peptides sauvagine, urotensin I, and urocortin may play roles in the central nervous system and the periphery. The wide distribution and region-specific expression of CRH-like peptides suggests that these molecules subserve different functions within the brain and the hypothalamo-hypophyseal axis. In mammals, the actions of $\mathrm{CRH}$ peptides, in addition to their hypophysiotropic role, include control of appetite, behavioral responses to stress (arousal, escape), and modulation of immune responses, among others. 15

While screening for neuropeptides with TSH-releasing factor (TRF) activity in nonmammalian vertebrates, we discovered that $\mathrm{CRH}$-like peptides are potent TSH secretagogues in amphibians and reptiles. ${ }^{19,20} \mathrm{CRH}$ has since been shown to stimulate the thyroid axis in a fish, several amphibians, a reptile, and a bird. Injections of CRH cause elevations in whole-body TH levels in tadpoles $21,22,23$ and plasma TH levels in the chick embryo ${ }^{24}$ and the frog, Rana ridibunda. ${ }^{25}$ Tissue culture studies using pituitaries from representatives of each nonmammalian vertebrate class have shown that the stimulation of TSH release by CRH occurs through a direct action on the anterior pituitary. In species where a specific TSH radioimmunoassay is not yet available, the release of TSH was monitored by bloassay (amphibians ${ }^{11,19,26}$ ) or by a subtractive method using specific RIAs for the gonadotropin beta subunits and the alpha subunit (chicken ${ }^{25,27}$ ). Specific radloimmunoassays for TSH in the salmon and turtle have verified that the thyrotropic activity released in response to $\mathrm{CRH}$ is authentic TSH (turtle ${ }^{20}$; salmon ${ }^{28}$ ). It is highly likely that CRH stimulates the release of authentic TSH in amphibians. This conclusion is based upon the observation that $\mathrm{CRH}$ induces the rapid release of thyrotropic activity by tadpole and adult frog pituitaries cultured in vitro, ${ }^{11,19,26}$ (a specific amphibian TSH RIA is not yet available). Furthermore, Xenopus tadpole pituitaries cultured in the presence of CRH exhibit a marked increase in the secretion of a protein with TSH immunoreactivity (determined by Western blot using anti-human TSH $\beta$ serum which crossreacts with frog TSH; unpublished results). Significantly, while CRH is a potent TRF on cultured salmon pituitaries, the tripeptide TRH is without activity in controlling TSH release. ${ }^{28}$ Thus, CRH is a potent TRF in representatives of all nonmammalian vertebrates that have been studied. A primitive role for $\mathrm{CRH}$ (and a role maintained in perhaps the majority of extant vertebrate species) may have been to regulate both the thyroid and the interrenal (adrenal) axes. Whether CRH acts directly on thyrotropes via a specific CRH receptor is currently unknown. It is also possible that CRH stimulates corticotropes to release a paracrine-acting factor with TSH-releasing activity.

\section{THE CRH RECEPTORS AND BINDING PROTEIN ARE EVOLUTIONARILY CONSERVED}

In mammals, four distinct $\mathrm{CRH}$ receptors and one secreted binding protein (CRHBP) have been identified. The receptors appear homologous, each being a sev- 
en-transmembrane domain $\mathrm{G}$ protein-linked receptor, and each transducing extracellular signals by stimulating intracellular cAMP production. ${ }^{13}$ The receptors exhibit differential rank-order affinities for $\mathrm{CRH}$ peptides and tissue-specific patterns of expression. The $\mathrm{CRHR}_{1}$ is a 415 -amino-acid protein that does not discriminate among $\mathrm{CRH}$-like peptides (i.e., it possesses high affinity for all). $\mathrm{CRHR}_{1}$ is expressed in the pituitary and in neocortical, cerebellar, and sensory relay structures in the brain. The $\mathrm{CRHR}_{2}$, which is $70 \%$ homologous to $\mathrm{CRHR}_{1}$, has at least three splicing variants $\left(\mathrm{CRHR}_{2 \alpha}-411\right.$ a.a.; $\mathrm{CRHR}_{2 \beta^{-4}} 431$ a.a.; $\mathrm{CRHR}_{2 \gamma^{-}}-397$ a.a.), each possessing significantly higher affinity for urocortin, $\mathrm{SV}$, and UI than for CRHs. CRHR 2 expression is localized to the lateral septal nuclei and regions of the hypothalamus; within the hypothalamus this receptor could play an important role in CRH autoregulation. ${ }^{13}$

Similar receptor proteins exist in the frog Xenopus laevis, although there is no evidence for splice variants of the $\mathrm{CRHR}_{2} \cdot{ }^{29}$ The Xenopus receptors exhibit similar rank-order affinities for different $\mathrm{CRH}$-like peptides as their mammalian counterparts, with the exception that $\mathrm{xCRHR}_{1}$ exhibits low affinity for $\mathrm{SV}$ in contrast with mammalian $\mathrm{CRHR}_{1} \cdot{ }^{29}$ As in mammals, $\mathrm{CRHR}_{1}$ is expressed in the adult Xenopus pituitary, while $\mathrm{CRHR}_{2}$ is not. ${ }^{29}$ However, nothing is yet known of the tissue distribution, developmental expression, or hormonal regulation of the CRHRs in amphibians.

Recent demonstrations of the presence of a secreted binding protein for CRH $(\mathrm{CRHBP})^{30}$ suggests another important site for modulation of CRH activity. This 322-amino-acid protein is expressed in multiple tissues in mammalian species, including the liver, brain, and pituitary gland. CRHBP circulates in the blood in humans, but not in rats, which may be explained by the lack of expression in rat liver. Recently, the homologous Xenopus CRHBP was cloned as a $\mathrm{T}_{3}$-regulated gene from tadpole tail ${ }^{31}$ and we have shown that this gene is expressed in brain (Valverde and Denver, unpublished material). The role that this protein plays in modulating CRH action is poorly understood, and comparative studies in species other than mammals are thus far lacking. Some possible functions include modulation of CRH action by blocking the bioavailability of $\mathrm{CRH}$ or targeting the peptide for clearance, as has been suggested in human pregnancy. ${ }^{30}$ Alternatively, the CRHBP could function to maintain high levels of CRH in the blood or within tissues, thus facilitating the action of the peptide. It has been suggested that the upregulation of this protein during metamorphic climax might serve a negative feedback function by sequestering $\mathrm{CRH}$ and thus modulating its bioavailability. ${ }^{31}$ The accessibility of the tadpole makes it a valuable animal model for defining roles for this protein in animal development.

\section{EXOGENOUS CRH INDUCES METAMORPHOSIS IN AMPHIBIAN LARVAE}

Studies from several labs have shown that $\mathrm{CRH}$ is capable of accelerating tadpole metamorphosis. For example, Gancedo and colleagues ${ }^{21}$ showed that CRH stimulates metamorphosis and elevates whole-body $\mathrm{TH}$ content in the ranid frog Rana perezi. My studies showed that $\mathrm{CRH}$ accelerates metamorphosis and elevates wholebody thyroid hormone in the ranid frog Rana catesbeiana and the pelobatid toad Scaphiopus hammondii. ${ }^{22,23} \mathrm{CRH}$ also accelerates metamorphosis in the bufonid 
Bufo arenarum (L. Miranda, personal communication) and in the ambystomatid salamander Ambystoma tigrinum (Boorse and Denver, unpublished observations).

\section{ENDOGENOUS CRH FUNCTIONS AS A PHYSIOLOGICAL MEDIATOR OF STRESS-INDUCED METAMORPHOSIS}

A role for endogenous $\mathrm{CRH}$ in controlling spontaneous metamorphosis was first suggested by my findings with tadpoles of the bullfrog, Rana catesbeiana, in which passive immunization with CRH antiserum slowed spontaneous metamorphosis. ${ }^{22}$ This finding suggests a physiological role for CRH in controlling spontaneous metamorphosis. Our ability to alter metamorphic timing in the lab by altering environmental conditions ${ }^{32}$ has allowed us to test the hypothesis that endogenous CRH participates in environmentally induced (stress-induced) metamorphosis. ${ }^{23}$

Probably the most important environmental variable for a tadpole is water availability, and pond duration can profoundly influence the rate of metamorphosis in some species. 5,23,32 Desert amphibians tend to breed in ephemeral habitats; pools are sporadically filled by rainfall and then dry at different rates, depending on a combination of geologic and climatic factors. Because these species exhibit facultative timing of metamorphosis they are ideal model systems for studying the physiological mechanisms of phenotypic plasticity. Our studies in the western spadefoot toad $S$. hammondii show that metamorphosis can be accelerated in the laboratory by reducing the water level of the aquaria that the tadpoles are raised in. ${ }^{5,23,32}$ Furthermore, this developmental response is reversible until metamorphic climax: shifting tadpoles back to a high water environment restores body mass and decelerates metamorphosis (i.e., release from ecological stress ${ }^{32}$ ).

As mentioned above, injections of CRH-like peptides accelerated metamorphosis in the western spadefoot toad, S. hammondii. ${ }^{5,23}$ Conversely, the developmental acceleration induced by water volume reduction was attenuated by injection of the $\mathrm{CRH}$ receptor antagonist $\alpha$-helical $\mathrm{CRH}_{(9-41)}$ or by passive immunization with anti$\mathrm{CRH}$ serum. Tadpoles exhibited elevated hypothalamic $\mathrm{CRH}$ concentrations at the time that they first responded (morphologically and endocrinologically) to the water volume reduction. ${ }^{23}$ Tadpoles subjected to water volume reduction also exhibited a precocious elevation in whole-body TH and CORT contents. ${ }^{33}$ Taken together with the findings that $\mathrm{CRH}$ injections can accelerate metamorphosis in several amphibian species, these data point to a central role for CRH in controlling stress-induced (and perhaps also spontaneous) metamorphosis.

\section{CRH MAY BE A PHYLOGENETICALLY ANCIENT DEVELOPMENTAL SIGNALING MOLECULE}

CRH may represent a phylogenetically ancient developmental signaling molecule that vertebrates use to assess changes in their habitat and to respond accordingly. Recent data in mammalian species including humans show that CRH of fetal and/or placental origin functions as a timing mechanism regulating the length of the gestational period and perhaps shortening gestation under situations of fetal stress. ${ }^{34}$ The 
action of CRH in tadpole metamorphosis suggests that the action of this hormone in controlling the developmental response of the larva/fetus to environmental stress arose early in vertebrate evolution.

\section{SUMMARY AND CONCLUSIONS}

$\mathrm{CRH}$ is a versatile adaptive hormone, promoting survival through maintenance of homeostasis and beneficial behaviors in response to stressful situations. Our ecological and endocrinological studies suggest that tadpoles use special senses to detect a desiccating habitat and mount a classical neuroendocrine stress response. The CRH neuron is likely to be an important transducer of the environmental signal into an endocrine response leading to accelerated metamorphosis. In tadpoles, the $\mathrm{CRH}$ signal is transduced by at least two receptor subtypes and may be modulated by a secreted binding protein. Evolutionary conservation of the role of $\mathrm{CRH}$ in mediating developmental plasticity is suggested by recent demonstrations in mammals that $\mathrm{CRH}$ of fetal and/or placental origin determines the length of the gestational period. Furthermore, elevations in fetal $\mathrm{CRH}$ under conditions of intrauterine stress may precipitate preterm birth.

\section{ACKNOWLEDGEMENTS}

This research was supported by NSF Grant IBN 9496321 and by funds from the office of the Vice President for Research and the College of Literature, Science and the Arts at the University of Michigan.

\section{REFERENCES}

1. Gibson, G. \& D.S. Hogness. 1996. Effect of polymorphism in the Drosophila regulatory gene Ultrabithorax on homeotic stability. Science 271: 200-203.

2. Stearns, S.C. 1989. The evolutionary significance of phenotypic plasticity. BioScience 39: 436-445.

3. Newman, R.A. 1992. Adaptive plasticity in amphibian metamorphosis. Biosciences 42: 671-678.

4. West-Eberhard, M.J. 1989. Phenotypic plasticity and the origins of diversity. Annu. Rev. Ecol. Systematics 20: 249-278.

5. Denver, R.J. 1997. Proximate mechanisms of phenotypic plasticity in amphibian metamorphosis. Am. Zool. 37: 172-184.

6. Gudernatsch, J.F. 1912. Feeding experiments on tadpoles. 1. The influence of specific organs given as food on growth and differentiation. A contribution to the knowledge of organs with internal secretion. Wilhelm Roux Arch. Entwicklungsmech. Organismen 35: 457-483.

7. Galton, V.A. 1992. The role of thyroid hormone in amphibian metamorphosis. Trends Endocrinol. Metab. 3: 96-100.

8. Kikuyama, S., K. Kawamura, S. Tanaka \& K. Yamamoto. 1993. Aspects of amphibian metamorphosis: hormonal control. Int. Rev. Cytol. 145: 105-148.

9. Denver, R.J. 1996. Neuroendocrine control of amphibian metamorphosis. In Metamorphosis: Post-Embryonic Reprogramming of Gene Expression in Amphibian and Insect Cells. J. R. Tata, L. I. Gilbert \& E. Frieden, Eds.: 433-464. Academic Press. San Diego, CA. 
10. Licht, P. \& R.J. Denver. 1990. Regulation of thyrotropin secretion. In Progress in Comparative Endocrinology. A. Epple, C.G. Scanes \& M.H. Stetson, Eds.: 427432. Wiley-Liss. New York.

11. Denver, R.J. \& P. Licht. 1989 Neuropeptide stimulation of thyrotropin secretion in the larval bullfrog: evidence for a common neuroregulator of thyroid and interrenal activity during metamorphosis. J. Exp. Zool. 252: 101-104.

12. Jacobs, G.F.M., R.P.A. Michielsen \& E.R. KuHn. 1988. Thyroxine and triiodothyronine in plasma and thyroids of the neotenic and metamorphosed axolotl Ambystoma mexicanum: Influence of TRH injections. Gen. Comp. Endocrinol. 70: $145-151$.

13. Turnbull, A.V. \& C. Rivier. 1997. Corticotropin-releasing factor (CRF) and endocrine responses to stress: CRF receptors, binding protein and related peptides. Proc. Soc. Exp. Biol. Med. 215: 1-10.

14. Tonon, M. C., P. Cuet, M. Lamacz, J. Jegou, J. Cote, L. Gouteux, N. Ling, G. Pelleier \& H. VAUdRY. 1986. Comparative effects of corticotropin-releasing factor, arginine vasopressin, and related neuropeptides on the secretion of ACTH and $\alpha-\mathrm{MSH}$ by frog anterior pituitary cells and neurointermediate lobes in vitro. Gen. Comp. Endocrinol. 61: 438-445.

15. Vale, W., J. Vaughan \& M. Perrin. 1997. Corticotropin-releasing factor (CRF) family of ligands and their receptors. Endocrinologist 7: S3-S9 (Suppl.).

16. Lederis, K., J.N. Fryer, Y. Okawara, C. Schronrock \& D. Richter. 1994. Corticotropin-releasing factors acting on the fish pituitary: experimental and molecular analysis. In Fish Physiology, Molecular Endocrinology. N.M. Sherwood \& C.L. Hew, Eds.: 67-100. Academic Press. San Diego, CA.

17. Montecucchi, P.C. \& A. Henschen. 1981. Amino acid composition and sequence analysis of sauvagine, a new active peptide from the skin of Phyllomedusa sauvagei. Int. J. Pept. Protein Res. 18: 113-120.

18. Vaughan, J., C. Donaldson, J. Bittencourt, M.H. Perrin, K. Lewis, S. Sutton, R. Chan, A.V. Turnbull, D. Lovejoy, C. Rivier, J. Rivier, P.E. Sawchenko \& W. VALE. 1995. Urocortin, a mammalian neuropeptide related to fish urotensin I and to corticotropin-releasing factor. Nature 378: 287-292.

19. DENVER, R.J. 1988. Several hypothalamic peptides stimulate in vitro thyrotropin secretion by pituitaries of anuran amphibians. Gen. Comp. Endocrinol. 72: 383-393.

20. Denver, R.J. \& P. Licht. 1989. Neuropeptides influencing pituitary hormone secretion in hatchling turtles. J. Exp. Zool. 251: 306-315.

21. Gancedo, B., I. Corpas, A.L. Alonso-Gomez, M.J. Delgado, G. Morreale De Escobar \& M. Alonso-Bedate. 1992. Corticotropin-releasing factor stimulates metamorphosis and increases thyroid hormone concentration in prometamorphic Rana perezi larvae. Gen. Comp. Endocrinol. 87: 6-13.

22. Denver, R.J. 1993. Acceleration of anuran amphibian metamorphosis by corticotropin-releasing hormone-like peptides. Gen. Comp. Endocrinol. 91: 38-51.

23. Denver, R.J. 1997. Environmental stress as a developmental cue: corticotropinreleasing hormone is a proximate mediator of adaptive phenotypic plasticity in amphibian metamorphosis. Horm. Behav. 31: 169-179.

24. Meeuwis, R., R. Michielsen, E. Decuypere \& E.R. Kuhn. 1989. Thyrotropic activity of the ovine corticotropin-releasing factor in the chick embryo. Gen. Comp. Endocrinol. 76: 357-363.

25. Kuhn, E.R., K.L. Geris, S. van der Geyten, K.A. Mol \& V.M. Darras. 1998. Inhibition and activation of thethyroidal axis by the adrenal axis in vertebrates. Comp. Biochem. Physiol. A 120: 169-174.

26. JACOBS, G.F.M. \& E.R. KUHN. 1992. Thyroid hormone feedback regulation of the secretion of bioactive thyrotropin in the frog. Gen. Comp. Endocrinol. 88: 415-423. 
27. Geris, K.L., S.P. Kotanen, L.R. Berghman, E.R. Kuhn \& V.M. Darras. 1996. Evidence of a thyrotropin-releasing activity of ovine corticotropin-releasing factor in the domestic fowl (Gallus domesticus). Gen. Comp. Endocrinol. 104: 139-146.

28. Larsen, D.A., P. Swanson, J.T. Dickey, J. Rivier \& W.W. Dickhoff. 1998. In vitro thyrotropin-releasing activity of corticotropin-releasing hormone-family peptides in coho salmon, Oncorhynchus kisutch. Gen. Comp. Endocrinol. 109: 276-285.

29. Dautzenberg, F.M., K. Dietrich, M.R. Palchaudhuri \& J. Spiess. 1997. Identification of two corticotropin-releasing factor receptors from Xenopus laevis with high ligand selectivity: unusual pharmacology of the type 1 receptor. J. Neurochem. 69: 1640-1649.

30. Behan, D.P. De Souza, E.B. Potter, E. Sawchenko, P. Lowry, P.J. \& W.W. Vale, 1996. Modulatory actions of corticotropin-releasing factor-binding protein. Ann. N.Y. Acad. Sci. 780: 81-95.

31. Brown, D.D., Z. Wang, J.D. Furlow, A. Kanamori, R.A. Schwartzman, B.F. Remo \& A. PINDER. 1996. The thyroid hormone-induced tail resorption program during Xenopus laevis metamorphosis. Proc. Natl. Acad. Sci. USA 93: 1924-1929.

32. Denver, R.J., N. Mirhadi \& M. Phillips. 1998. Adaptive plasticity in amphibian metamorphosis: response of Scaphiopus hammondii tadpoles to habitat desiccation. Ecology 79: 1859-1872.

33. DenVER, R.J. 1998. Hormonal correlates of environmentally induced metamorphosis in the Western spadefoot toad, Scaphiopus hammondii. Gen. Comp. Endocrinol. 110: $326-336$.

34. SMIth, R. 1998. Alterations in the hypothalamic pituitary adrenal axis during pregnancy and the placental clock that determines the length of parturition. J. Reprod. Immunol. 39: 215-220. 